\title{
PENGARUH PENGETAHUAN KEUANGAN, RISK TOLERANCE TERHADAP INVESTASI SAHAM, DIMODERASI GENDER
}

Indah Yuni Kurniawati S

Sekolah Tinggi Ilmu Ekonomi Perbanas Surabaya

\begin{abstract}
This study aims to determine the effect of financial knowledge and tolerance on stock investment decisions (corporate self-image, reference information and financial information), with data analysis techniques using SEM on WarpPLS, there are 112 respondents with those in accordance with this study. Based on the results of the study, financial knowledge has a significant negative effect on the company's self-image and referral information, but a significant positive effect on financial information. Risk tolerance has only a significant positive effect on financial information and does not have a significant effect on corporate self-image and referral information. Gender cannot moderate the effect of risk tolerance on stock investment decisions.
\end{abstract}

Keywords : stock investment, knowledge, risk tolerance

Correspondence to : indahyuniks7@gmail.com

\section{PENDAHULUAN}

Tandelilin (2010:2) menyatakan bahwa investasi merupakan penempatan atas sejumlah dana atau sumber daya lainnya yang dilakukan pada saat ini, dengan tujuan memperoleh sejumlah keuntungan di masa datang.Penempatan dana untuk keputusan investasi umumnya dibedakan menjadi dua, yaitu financial asset dan real asset.Financial asset adalah sektor investasi dengan cara menamamkan modalnya pada instrumeninstrumen keuangan di pasar modal maupun di pasar uang (Abdul Halim, 2005). Dalam membuat keputusan investasi seorang investor akan dipengaruhi oleh sikapnya baik yang rasional maupun irasional. Seorang investor yang memiliki sikap rasional tercemin ketika investor tersebut dalam pengambilan keputusan investasi berdasarkan pengetahuan keuangan yang dimiliki (Huston, 2010). Menurut Al-Tamimi dan Kalli (2009), pengetahuan keuangan dapat mempengaruhi seorang investor dalam pengambilan keputusan investasi, semakin tinggi pengetahuan investor tentang keuangan maka investor tersebut akan menempatkan dananya pada investasi yang lebih beresiko. Sebaliknya jika seorang investor memiliki sikap irasional maka seseorang tersebut ketika mengambil keputusan investasi berfikir tidak berdasarkan akal. Sikap irasional seorang investor dapat dipengaruhi oleh faktor psikologis dan demografi, salah satu faktor psikologis diantaranya yaitu risk tolerancehal ini menggambarkan sikap investor dalam menyikapi sebuah risiko.

Saham adalah sebuah bukti kepemilikan atas sebuah perusahaan / badanusaha.Pasar modal merupakan salah satu alternatif investasi jangka panjang bagi para pemodal yang akan menanamkan modalnya dalam investasi saham, dengan 
berinvestasi di pasar modal seorang investor saham akan mengharapkan sebuah return. Besar kecilnya return yang diharapkan tergantung keberanian investor bersedia dalam mengambil resiko. Seperti karakteristik saham yaitu high risk-high return, artinya semakin besar resiko yang diambil oleh seorang investor maka harapan terhadap return juga besar. Setiap pilihan investasi mempunyai tingkat keuntungan dan resiko yang berbeda, tingkat keuntungan dan resiko antar sahampun akan berbeda sekalipun dalam industri yang sama Real asset yaitu jenis investasi dengan menginvestasikan dana yang dimiliki pada aset real, contohnya seperti tanah, bangunan, mesin, dan sebagainya. Menurut Al-Tamimi \& Kalli (2009) menyatakan bahwa dalam keputusan investasi saham terdiri 3 dimensi yaitu diantaranya citra diri perusahaan, informasi rujukan dan informasi keuangan.

Banyak berbagai macam faktor yang dapat mempengaruhi keputusan investasi saham diantaranya yaitu pengetahuan keuangan dan risk tolerance.

Pengetahuan dapat digunakan oleh seorang investor saham untuk mengelola keuangan agar dapat membatasi pengeluaran yang kurang bermanfaat sehingga bisa menyisihkan pedapatannya untuk berinvestasi. Hilgert et al (2003) menyatakan bahwa seseorang yang memiliki pengetahuan keuangan cenderung untuk berperilaku dengan cara yang bertanggung jawab. Seorang investor saham yang kurang pengetahuan keuangan akan menyebabkan bergantung pada orang lain dalam mengambil keputusan keuangan, sehingga pengetahuan keuangan memiliki pengaruh yang besar terhadap keputusan investasi saham. Investor saham yang memiliki pengetahuan baik akan cenderung mengabaikan citra diri perusahaan dan informasi rujukan dalam pengambilan keputusan investasi sahamnya, hal ini mengingat bahwa investor yang memiliki pengetahuan yang baik cenderung memiliki tingkat percaya diri yang tinggi (Al-Tamimi dan Kalli, 2009).

Menginvestasikan sebuah dana dalam pasar modal sangat memiliki risiko yang tinggi, hal ini karena perubahan harga saham sangat cepat. Oleh karena itu, tindakan investor dalam menyikapi suatu risiko sangat mempengaruhi dalam pengambilan keputusan. Tindakan investor dalam menyikapi sebuah risiko disebut juga sebagai risk tolerance. Risk toleranceadalah kesediaan seseorang untuk terlibat dalam kondisi dengan suatu tujuan yang diinginkan, tetapi pencapaian tujuan tidak pasti dan disertai olehprobabilitas kehilangan atau kegagalan(Kogan dan Michael, 1964).Menurut Kavita dan Prasaranna (2016) hanya para investor yang memiliki toleran resiko tinggi yang akan bersedia berinvestasi di saham, tinggi rendahnya toleransi resiko seorang investor didukung oleh tingkat pengetahuan yang mereka miliki, mayoritas seorang investor yang memiliki pengetahuan banyak akan memiliki toleransi resiko yang tinggi. Oleh karena itu, investor saham yang memiliki toleransi resiko akan cenderung mengabaikan citra diri perusahaan dan informasi rujukan dalam pengambilan keputusan investasi sahamnya.

Menurut Syed dan Khaliquzzaman (2016) menyatakan bahwa menabung adalah kebiasaan yang lebih sering dilakukan oleh wanita. Bahkan pada masa jaman lalu, ketika wanita bergantung pada pendapatan pasangan mereka (pria), mayoritas digunakan untuk menabung untuk memenuhi keadaan darurat serta untuk masa depan.Di dunia modern saat ini di manaperempuan lebih berpendidikan, lebih banyak bekerja dan berpengetahuan luas,mereka sudah mulai mengambil keputusan investasi mereka sendiri. Sebuah studi oleh Jianakoplosdan Bernasek (1998) menyatakanbahwa investor wanitacenderung kurang mengambil risiko dibandingkan lakilaki. 


\section{METODE PENELITIAN}

\section{Kerangka Pemikiran}

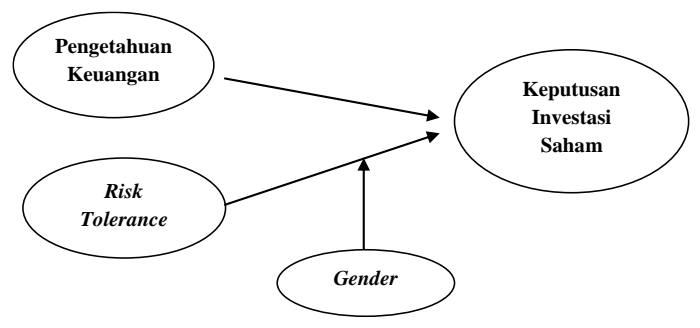

Gambar 1. Kerangka Pemikiran

Dimana :

$\mathrm{Y}=$ Keputusan Investasi Saham

$\mathrm{X} 1=$ Pengetahuan Keuangan

$\mathrm{X} 2=$ Risk Tolerance

$\mathrm{X} 3=$ Gender (variabel moderasi)

$\alpha=$ konstanta

$\beta 1 \beta 2=$ koefisien regresi yang akan diuji

$\mathrm{e}=$ error terms

Dimana Variabel Y terdiri dari 3 dimensi yaitu :

Y1 = Citra Diri Perusahaan

Y2 = Informasi Rujukan

Y3 = Informasi Keuangan

\section{Hipotesis Penelitian}

Dari kerangka pemikiran di atas, dapat disusun hipotesis penelitian sebagai berikut : H1 : Pengetahuan keuangan berpengaruhsignifikan terhadap keputusan invesatasi saham.

H2 : Risk Tolerance berpengaruh signifikan terhadap keputusan investasi saham.

H3 : Gender memoderasi pengaruh risk tolerance terhadap keputusan investasi saham terhadap keputusan invesatasi saham.

\section{Klarifikasi Sampel}

Populasi yang digunakan pada penelitian ini adalah investor saham. Teknik pengambilan Sampel yang digunakan adalah purposive sampling dan convenience sampling. Teknik pengambilan sampel purposive sampling adalah teknik pengambilan data yang digunakan dengan berbagai kriteria sesuai yang dibutuhkan dalam penelitian. Kriteria sampel pada penelitian ini yaitu:

1. Investor saham

2. Investor dengan pendapatan keluarga minimal Rp. 4.000.000

3. Pengalaman investasi di saham minimal $\geq 12$ bulan

Pada tahap selanjutnya, pengambilan sampel menggunakan convenience sampling, yaitu prosedur untuk mendapatkan unit sampel menurut keinginan peneliti (Mudrajad Kuncoro, 2013:138), dimana sampel ini akan mudah dijangkau dan didapatkan oleh peneliti, untuk mendapatkan unit sampel yang mudah dijangkau, maka peneliti menyebarkan kuesioner pada beberapa perusahaan sekuritas diantaranya adalah Mandiri Sekuritas, Sinar Mas Sekuritas, BCA Sekuritas, Galeri Investasi serta menggunakan Google Form dalam menyebarkan kuesioner.

\section{Definisi Operasional Variabel Keputusan Investasi}

Keputusan investasi yang dimaksud dalam penelitian ini adalah pertimbangan yang dilakukan seorang investor dalam memilih jenis investasi tertentu untuk mendapatkan keuntungan dimasa datang. Penilaian keputusan investasi dapat dilihat dari faktor yang menentukan besarnya dana yang akan diinvestasikan pada pasar modal (saham). Ada beberapa dimensi yang dapat mengukur keputusan investasi pada saham yaitu citra diri perusahaan, informasi rujukan dan informasi keuangan. Variabel keputusan investasidiukur dengan skala Likert dengan lima kategori respon yang dimulai dari skala 1 sampai 5 yaitu, (1) Tidak Pernah, (2) Pernah, (3) Jarang, (4) Sering, dan (5) Sangat sering.

\section{Pengetahuan Keuangan}

Pengetahuan yang dimaksud dalam penelitian ini adalah kemampuan seseorang mengenai aktivitas keuangan yang lebih 
Vol. XVII No. 1 | Bulan Januari Tahun 2020

spesifik yang akan dihadapi seperti pencatatan dan penganggaran, perbankan dan penggunaan kredit, simpanan dan pinjaman, pembayaran pajak, investasi, dan rencana pensiun, sehingga dibuthkan keterampilan untuk menerapkan pengetahuan tersebut. Ada beberapa indikator yang dapat mengukur pengetahuan keuangan yaitu General Personal Finance Knowledge, Saving and Borrowing, dan Investment. Dalam mengukur pengetahuan keuangan, akan digunakan skala rasio dengan membagi jumlah jawaban yang benar dengan banyaknya jumlah soal.

$$
\text { Pengetahuan Keuangan }=\frac{\text { Jumlah Jawaban Benar }}{\text { Jumlah Soal }}
$$

\section{Risk Tolerance}

Risk Tolerance adalah suatu tindakan atau sikap seorang investor dalam menyikapi sebuah resiko. Seorang investor yang ingin menanamkan modalnya di pasar modal seperti salah satu contohnya yaitu saham harus memiliki risk tolerance yang tinggi, hal ini karena investasi saham memiliki resiko yang tinggi sebab perubahan harga saham sangat cepat.

Variabel risk tolerance diukur dengan skala scoring yang digunakan dalam metode survei. Berikut ini adalah indikator yang digunakan untuk mengukur risk tolerance :

a. Penggunaan pendapatan untuk investasi yang bersifat spekulasi

b. Pembelian instrumen tanpa pertimbangan

c. Investasi pada kegiatan yang memberikan return besar

\section{HASIL PENELITIAN}

\section{Uji Validitas dan Uji Realibilitas}

Berikut Tabel 1 menyajikan uji validitas dan uji realibilitas variabel keputusan investasi .

TABEL 1. Uji Validitas dan Realibilitas

\begin{tabular}{|c|c|c|c|c|}
\hline Variabel & Item & Pernyataan & $\begin{array}{c}\text { Uji } \\
\text { Validitas }\end{array}$ & $\begin{array}{c}\text { Uji } \\
\text { Reliabilitas }\end{array}$ \\
\hline \multirow{3}{*}{$\begin{array}{c}\text { Keputusan } \\
\text { Investasi Saham } \\
\text { (Citra Diri } \\
\text { Perusahaan = } \\
\text { Y1) }\end{array}$} & KI.2 & $\begin{array}{l}\text { Saya memperhatikan posisi perusahaan dalam } \\
\text { industri sebagai citra diri dalam investasi saham }\end{array}$ & $\begin{array}{c}0.456 \\
(\text { Valid })\end{array}$ & \multirow{3}{*}{$\begin{array}{c}0.699 \\
\text { (Reliabel) }\end{array}$} \\
\hline & KI.3 & $\begin{array}{l}\text { Saya memperhatikan kepedulian perusahaan } \\
\text { terhadap masalah masyarakat sebagai citra diri } \\
\text { dalam investasi saham }\end{array}$ & $\begin{array}{l}0.700 \\
(\text { Valid })\end{array}$ & \\
\hline & KI.4 & $\begin{array}{l}\text { Saya memperhatikan produk dan layanan } \\
\text { perusahaan sebagai citra diri dalam investasi } \\
\text { saham }\end{array}$ & $\begin{array}{c}0.804 \\
\text { (Valid) }\end{array}$ & \\
\hline \multirow{2}{*}{$\begin{array}{l}\text { Keputusan } \\
\text { Investasi Saham } \\
\text { (Informasi } \\
\text { Rujukan = Y1) }\end{array}$} & KI.5 & $\begin{array}{l}\text { Saya memperhatikan reputasi dewan direksi } \\
\text { sebagai citra diri dalam investasi saham }\end{array}$ & $\begin{array}{c}0.802 \\
(\text { Valid })\end{array}$ & \multirow{2}{*}{$\begin{array}{c}0.782 \\
\text { (Reliabel) }\end{array}$} \\
\hline & KI.8 & $\begin{array}{l}\text { Saya memperhatikan produk dan layanan } \\
\text { perusahaan sebagai citra diri dalam investasi } \\
\text { saham }\end{array}$ & $\begin{array}{c}0.802 \\
(\text { Valid })\end{array}$ & \\
\hline \multirow{2}{*}{$\begin{array}{l}\text { Keputusan } \\
\text { Investasi Saham } \\
\quad \text { (Informasi } \\
\text { Rujukan = Y1) }\end{array}$} & KI.9 & $\begin{array}{l}\text { Saya mempertimbangkan kinerja saham dimasa } \\
\text { lalu sebagai informasi keuangan dalam investasi } \\
\text { saham }\end{array}$ & $\begin{array}{l}0.802 \\
(\text { Valid })\end{array}$ & \multirow[t]{2}{*}{$\begin{array}{c}0.783 \\
\text { (Reliabel) }\end{array}$} \\
\hline & KI.12 & $\begin{array}{l}\text { Saya mempertimbangkan kemudahan menjual } \\
\text { kembalisaham sebagai informasi keuangan dalam } \\
\text { investasi saham }\end{array}$ & $\begin{array}{l}0.802 \\
(\text { Valid })\end{array}$ & \\
\hline
\end{tabular}

Berdasarkan pada Tabel 1, menjelaskan bahwa seluruh indikator keputusan investasi saham yaitu terdiri dari citra diri perusahaan, informasi rujukan dan informasi keuangan dikatakan valid karena memiliki nilai signifikansi berada diantara 0.4-07 (Mahfud Sholifin dan Dwi Ratmono,
2013). Tabel 1 menjelaskan ada beberapa indikator keputusan investasi saham yang dihapus diantaranya yaitu indikator dengan nomer item KI.1, KI.6, KI.7, KI.10 dan KI.11, indikator tersebut dihapus karena disampel kecil menunjukan bahwa indikator tersebut tidak valid dan memiliki nilai 
Vol. XVII No. 1 | Bulan Januari Tahun 2020

composite realibility $>0.6$, sehingga dapat disimpulkan bahwa indikator keputusan investasi saham adalah reliabel. Hasil dari uji validitas dan reliabilitas tersebut sesuai dengan standar yang telah dijelaskan pada Bab III, sehingga variabel pengambilan keputusan investasi dikatakan valid dan reliabel.

\section{Uji Deskriptif}

Analisis deskriptif memberikan gambaran secara menyeluruh mengenaivariabel-variabel penelitian melalui jawaban-jawaban yang diberikan oleh responden atas pertanyaan-pertanyaan yang ada pada instrumen penelitian.

Berdasarkan Tabel 2 pada bagian jenis kelamin dapat dilihat bahwa terdapat sebesar $69 \%$ responden berjenis kelamin laki-laki dan sisanya sebesar $31 \%$ responden berjenis kelamin perempuan. Dapat dijelaskan pula bahwa presentase terbesar usia responden adalah $>25$ tahun yaitu sebesar 59\%.

Berdasarkan Tabel 2 menunjukan bahwa responden dalam penlitian ini mayoritas sudah menikah yaitu sebesar $67 \%$ dan bagian pendidikan terakhir dapat dijelaskan bahwa presentase pendidikan terakhir responden adalah sarjana yaitu sebesar $90 \%$. Dapat dijelaskan pula bahwa presentase terbesar jenis pekerjaan responden adalah karyawan swasta yaitu sebesar $44 \%$.

Berdasarkan Tabel 2 dapat dijelaskan pula bahwa proporsi terbesar responden berdasarkan pendapatanadalah Rp. 6.000 .000 - Rp.8.000.000 yaitu sebesar 37\%.

TABEL 2 Karakteristik Responden

\begin{tabular}{cccc} 
Karakteristik & Klasifikasi & Jumlah & Persentase \\
\hline $\begin{array}{c}\text { Jenis } \\
\text { Kelamin }\end{array}$ & $\begin{array}{c}\text { Perempuan } \\
\text { Laki }\end{array}$ & $\begin{array}{c}35 \\
77\end{array}$ & $\begin{array}{c}31 \% \\
69 \%\end{array}$ \\
\hline \multirow{2}{*}{ Umur } & $\begin{array}{c}>25 \text { tahun } \\
\text { tahun }\end{array}$ & 15 & $13 \%$ \\
\cline { 2 - 4 } & $\begin{array}{c}>40-55 \\
\text { tahun }\end{array}$ & 25 & $59 \%$ \\
\hline
\end{tabular}

\begin{tabular}{|c|c|c|c|}
\hline & $\begin{array}{c}>55-40 \\
\text { tahun }\end{array}$ & 6 & $5 \%$ \\
\hline \multirow[b]{2}{*}{ Status } & Menikah & 78 & $67 \%$ \\
\hline & $\begin{array}{l}\text { Belum } \\
\text { Menikah }\end{array}$ & 38 & $33 \%$ \\
\hline \multirow{5}{*}{$\begin{array}{c}\text { Pendidikan } \\
\text { Terakhir }\end{array}$} & SMP & 0 & $0 \%$ \\
\hline & SMA & 2 & $1 \%$ \\
\hline & Diploma & 8 & $7 \%$ \\
\hline & Sarjana & 80 & $90 \%$ \\
\hline & Pascasarjana & 12 & $11 \%$ \\
\hline \multirow{5}{*}{ Pekerjaan } & $\begin{array}{c}\text { Pegawai } \\
\text { Negeri }\end{array}$ & 3 & $11 \%$ \\
\hline & Swasta & 49 & $44 \%$ \\
\hline & Wiraswasta & 30 & $27 \%$ \\
\hline & BUMN & 17 & $15 \%$ \\
\hline & Lainya & 3 & $3 \%$ \\
\hline \multirow{4}{*}{ Tanggungan } & 1 & 63 & $56 \%$ \\
\hline & 2 & 30 & $27 \%$ \\
\hline & 3 & 14 & $13 \%$ \\
\hline & 4 & 5 & $4 \%$ \\
\hline \multirow{4}{*}{ Pendapatan } & $4 \mathrm{JT}-6 \mathrm{JT}$ & 18 & $16 \%$ \\
\hline & $6 \mathrm{JT}-8 \mathrm{JT}$ & 42 & $37 \%$ \\
\hline & $8 \mathrm{JT}-10 \mathrm{JT}$ & 23 & $21 \%$ \\
\hline & $>10 \mathrm{JT}$ & 29 & $26 \%$ \\
\hline
\end{tabular}

Sumber: data diolah

TABEL 3. Hasil Analisis Deskriptif Keputusan Investasi

\begin{tabular}{|c|c|c|}
\hline \multirow{2}{*}{ Item } & \multicolumn{2}{|r|}{ Keterangan } \\
\hline & Mean & Makna \\
\hline KI.2 & 4.40 & $\begin{array}{l}\text { Sangat setuju dalam } \\
\text { memperhatikan posisi perusahaan } \\
\text { dalam industri. }\end{array}$ \\
\hline KI.3 & 4.44 & 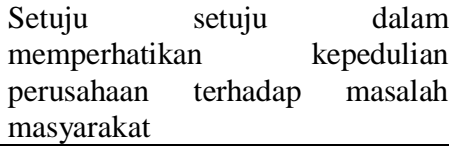 \\
\hline KI.4 & 4.28 & $\begin{array}{lr}\text { Sangat setuju } & \text { dalam } \\
\text { memperhatikan produk } & \text { dan } \\
\text { layanan perusahaan } & \\
\end{array}$ \\
\hline KI.5 & 3.26 & $\begin{array}{l}\text { Cukup setuju dalam } \\
\text { mempercayakan broker sebagai } \\
\text { sumber informasi }\end{array}$ \\
\hline KI.8 & 2.98 & $\begin{array}{l}\text { Cukup setuju dalam } \\
\text { mempercayakan koran sebagai } \\
\text { sumber informasi }\end{array}$ \\
\hline KI.9 & 4.03 & $\begin{array}{l}\text { Setuju dalam memperhatikan } \\
\text { kinerja saham dimasa lalu }\end{array}$ \\
\hline KI.12 & 3.94 & $\begin{array}{l}\text { Setuju dalam mempertimbangkan } \\
\text { kemudahan menjual saham } \\
\text { kembali }\end{array}$ \\
\hline
\end{tabular}

Sumber: data diolah 
Tabel 3 menunjukan bahwa jawaban responden terhadap pernyataan KI.2, KI.3 dan KI.4 adalah sangat setuju, artinya responden sangat memperhatikan posisi perusahaan dalam industri, kepedulian perusahaan terhadap masyarakat dan produk \& layanan perusahaan sebagai indikator citra diri perusahaan dalam mengambil keputusan investasi saham

Pada pernyataan KI.5dan KI.8 menunjukan bahwa jawaban responden cukup setuju terhadap pernyataan tersebut, artinya responden cukup memerlukan informasi rujukan dari broker dan koran dalam mengambil sebuah keputusa investasi saham.

Pada pernyataan KI.9 dan KI.12 juga menunjukan bahwa jawaban responden adalah setuju, artinya responden setuju dalam mempertimbangkan kinerja saham dimasa lalu dan kemudahan menjual kembali saham sebagai dalam keputusan investasinya.

TABEL 4. Hasil Analisis Deskriptif Pengetahuan Keuangan

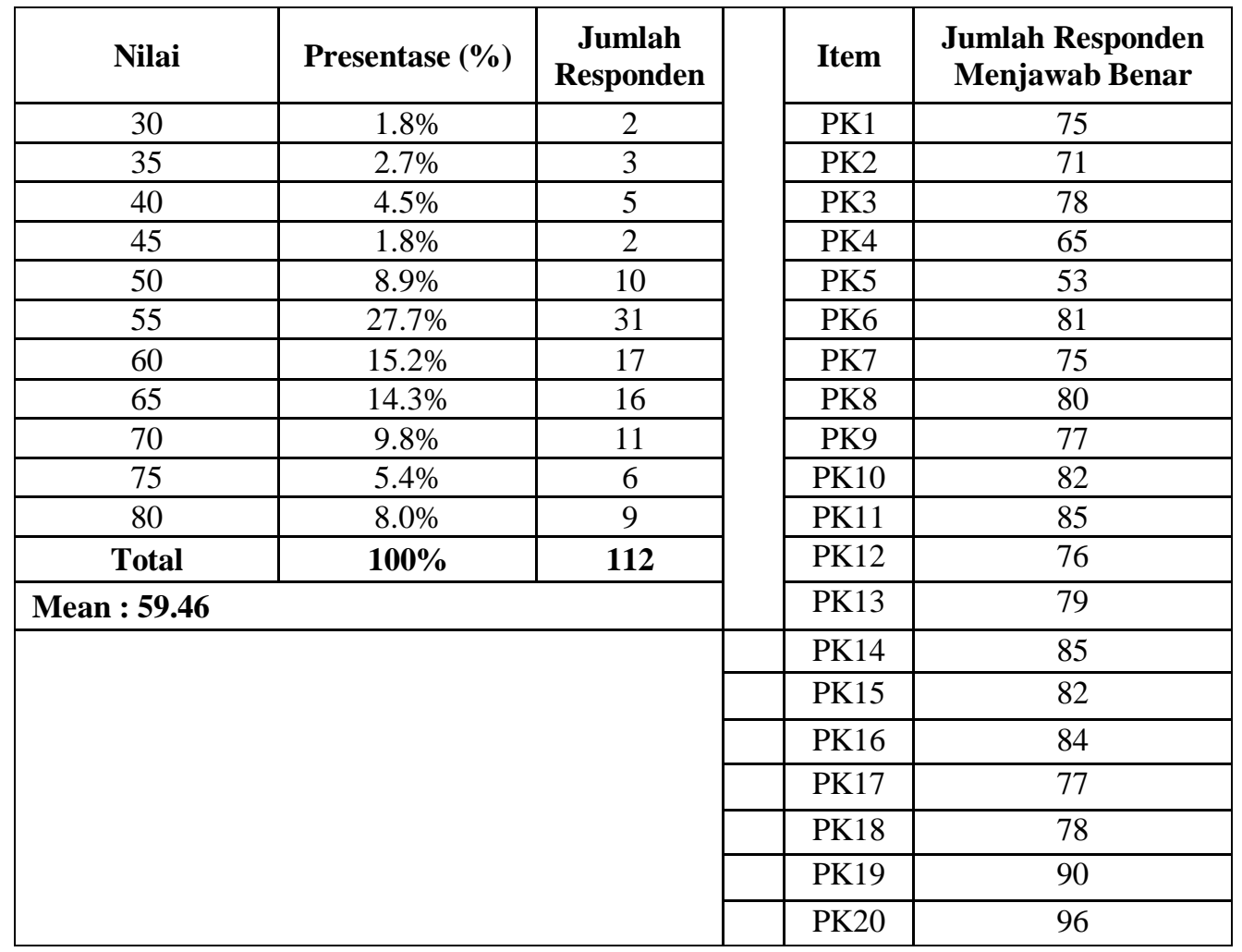

Tabel 4 menunjukan bahwa responden pada penelitian ini mayoritas memiliki nilai 55 yaitu dengan jumlah responden 31 orang atau $27.7 \%$, artinya responden hanya bisa menjawab 11 soal dari 20 soal yang ada. Skor tertinggi yang dicapai oleh responden yaitu dengan nilai 80 , hanya terdapat 9 responden yang memiliki nilai 80 . Jika berdasarkan skoring penilaian Chen dan Volpe (1998) bahwa seseorang yang memiliki skor <55 memiliki pengetahuan yang kurang baik, skor $>55-70$ memiliki pengetahuan yang cukup baik, >70-80 memiliki pengetahuan baik dan $>80$ memiliki pengetahuan yang sangat baik.

Pada tabel 4 menunjukan bahwa ratarata skoring dari responden dalam penilitian ini adalah 59.46, sehingga dapat disimpulkan bahwa responden dalam penelitian ini masih memiliki pengetahuan yang cukup baik. menunjukan skor pengetahuan keuangan menggunakan skala rasio yang menggunakan skala interval dalam melakukan analisis deskriptif <60 kurang baik, 60-80 artinya cukup baik dan $>80$ artinya sangat baik (Chen 
Vol. XVII No. 1 | Bulan Januari Tahun 2020

dan Volpe,1998). Tabel 5 menunjukan bahwa responden dari penelitian ini memiliki pengetahuan keuangan yang cukup baik hal ini ditunjukan dengan rata-rata presentase keseluruhan sebesar $67,7 \%$.

Pada tabel 4 juga menyajikan bahwa pada pertanyaan PK 5 hanya terdapat 53 responden dapat menjawab dengan benar, pada item tersebut mempertanyakan tentang bunga majemuk, sedangkan pertanyaan yang paling banyak responden menjawab benar yaitu pada item PK20 tentang pembagian keuntung saham (dividen).

TABEL 5. Hasil Analisis Deskriptif RiskTolerance

\begin{tabular}{ccc}
\hline Range & Keterangan & $\begin{array}{c}\text { Jumlah } \\
\text { Responden }\end{array}$ \\
\hline $10-<16$ & $\begin{array}{c}\text { Risk tolerance } \\
\text { rendah }\end{array}$ & 9 \\
\hline $16-<22$ & $\begin{array}{c}\text { Risk tolerance } \\
\text { sedang }\end{array}$ & 29 \\
\hline $22-<28$ & $\begin{array}{c}\text { Risk tolerance } \\
\text { tinggi }\end{array}$ & 53 \\
\hline $28-<34$ & $\begin{array}{c}\text { Risk tolerance } \\
\text { sangat tinggi }\end{array}$ \\
\hline & 21 \\
\hline
\end{tabular}

\section{Mean : $\quad$ 23.01}

Sumber: data diolah

Tabel 5 dapat menunjukan bahwa 53 responden responden dari penelitian ini memiliki risk tolerance yang tinggi dan hanya terdapat 9 responden yang memiliki risk tolerance rendah.

Pada tabel 5 juga menunjukan bahwa mean risk tolerance dari responden adalah 23.01 artinya responden pada penelitian ini memiliki rata - rata risk tolerance tinggi

\section{PEMBAHASAN}

Berikut tabel 6 untuk menjelaskan pengaruh antar dua atau lebih variabel independen dengan variabel dependen. Analisis ini digunakan untuk mengetahui apakah ada pengaruh antara pengetahuan keuangan dan risk tolerance terhadap keputusan investasi.

TABEL 6 Hasil Uji SEM Keputusan Investasi

\begin{tabular}{|c|c|c|c|c|c|c|c|}
\hline \multirow{2}{*}{$\begin{array}{l}\text { Keputusan } \\
\text { Investasi }\end{array}$} & \multicolumn{2}{|c|}{$\begin{array}{c}\text { Pengetahuan } \\
\text { Keuangan }\left(\mathbf{X}_{1}\right)\end{array}$} & \multicolumn{2}{|c|}{$\begin{array}{c}\text { Risk } \\
\text { Tolerance }\left(\mathrm{X}_{2}\right)\end{array}$} & \multirow{2}{*}{$R^{2}$} & \multicolumn{2}{|c|}{$\begin{array}{c}\text { Risk Tolerance } x \\
\text { Gender }\end{array}$} \\
\hline & B & Pvalue & B & Pvalue & & B & Pvalue \\
\hline $\begin{array}{l}\text { Citra Diri } \\
\text { Perusahaan }\left(Y_{1}\right)\end{array}$ & -0.30 & $* P<0.01$ & -0.12 & $P=0.10$ & -0.088 & -0.11 & $P=0.11$ \\
\hline $\begin{array}{l}\text { Informasi } \\
\text { Rujukan }\left(Y_{2}\right)\end{array}$ & -0.80 & $* \mathbf{P}<0.01$ & 0.08 & $P=0.21$ & 0.56 & -0.03 & $P=0.38$ \\
\hline $\begin{array}{l}\text { Informasi } \\
\text { Keuangan }\left(\mathrm{Y}_{3}\right)\end{array}$ & 0.28 & $* \mathbf{P}<0.01$ & 0.18 & $* \mathbf{P}=\mathbf{0 . 0 3}$ & 0.16 & -0.06 & $P=0.27$ \\
\hline
\end{tabular}

Variabel Pengetahuan Keuangan berdasarkan Tabel 6 dapat dikatakan bahwa berpengaruh negatif signifikan terhadap Citra Diri Perusahaan dan Informasi Rujukan, karena memiliki nilai Pvalue $<0.05$ yaitu < 0.01 dan bepengaruh positif signifikan terhadap Informasi Keuangan.

Variabel Risk Tolerance berdasarkan Tabel 6 nilai hanya berpengaruh positif signifikan pada informasi keuangan, karena memiliki nilai Pvalue $<0.05$ yaitu 0.03 dan tabel 6 menunjukan bahwa gender tidak dapat memoderasi pengaruh risk tolerance terhadap Citra Diri Perusahaan, Informasi Rujukan dan Informasi Keuangan.

Berdasarkan Tabel 6, pada persamaan pertama Y1 (Citra Diri Perusahaan) diperoleh nilai R2(R square) sebesar $-0,088$ atau $-8.8 \%$. Hal ini menunjukkan bahwa prosentase sumbangan pengaruh variabel pengetahuan 
keuangan dan risk tolerance terhadap Citra Diri Perusaaan sebesar $-8.8 \%$, sehingga dapat disimpulkan bahwa variabel pengetahuan keuangan dan risk tolerance tidak memiliki sumbangan pengaruh terhadap Citra Diri Perusahaan.

Berdasarkan Tabel 6, pada persamaan kedua Y2 (Informasi Rujukan) diperoleh nilai R2(R square) sebesar 0.56 atau 56\%. Hal ini menunjukkan bahwa prosentase sumbangan pengaruh variabel pengetahuan keuangan dan risk tolerance terhadap Informasi Rujukan sebesar 56\%, yang artinya variabel pengetahuan keuangan dan risk tolerance mampu menjelaskan sebesar $56 \%$ terhadap Informasi Rujukan pada keputusan investasi saham dan sisanya sebesar $44 \%$ dipengaruhi oleh variabel lain.

Berdasarkan Tabel 6, pada persamaan kedua Y3 (Informasi Keuangan) diperoleh nilai $\mathrm{R} 2(\mathrm{R}$ square) sebesar 0.16 atau $16 \%$. Hal ini menunjukkan bahwa prosentase sumbangan pengaruh variabel pengetahuan keuangan dan risk tolerance terhadap Informasi Keuangan sebesar 16\%, yang artinya variabel pengetahuan keuangan dan risk tolerance mampu menjelaskan sebesar 16\% terhadap Informasi Keuangan pada keputusan investasi saham dan sisanya sebesar $84 \%$ dipengaruhi oleh variabel lain.

Tujuan dari penelitian ini adalah untuk menguji adanya pengaruh Pengetahuan Keuangan dan Risk Tolerance terhadap Keputusan Investasi Saham dengan Gender sebagai variabel moderasi

Berikut adalah pembahasan terkait perumusan masalah dan pengujian hipotesis :

\section{Pengaruh Pengetahuan Keuangan} Terhadap Keputusan Investasi Saham

Hipotesis pertama dalam penelitian ini digunakan untuk membuktikan apakah pengetahuan keuangan mempengaruhi keputusan investasi saham. Berikut hasil pengujian hipotesis tersebut :

Pengetahuan Keuangan Terhadap Citra Diri Perusahaan (Y1)
Pengujian hipotesis diperoleh hasil yang menyatakan bahwa terdapat pengaruh negative signifikan.Hal ini dapat dilihat pada tabel 6 nilai $\mathrm{B}$ (beta) sebesar -0.30 dan memiliki Pvalue $\mathrm{P}<0.01$ artinya lebih kecil dari $(<) \quad 0.05$, sehingga dapat dikatakan bahwa Pengetahuan Keuangan memiliki pengaruh negative signifikan terhadap Citra Diri Perusahaan dalam Keputusan Investasi Saham. Artinya semakin baik pengetahuan keuangan yang dimiliki oleh seorang investor maka cenderung tidak mempertimbangkan Citra Diri Perusahaan dalam mengambil sebuah keputusan investasi saham.

Seorang investor yang kurang pengetahuan keuangan akan menyebabkan bergantung pada orang lain dalam mengambil keputusan keuangan, sehingga pengetahuan keuangan memiliki pengaruh yang besar terhadap keputusan investasi saham. Investor yang memiliki pengetahuan keuangan yang baik akan cenderung percaya diri dalam menempatkan dananya dalam sebuah investasi tidak peduli mengenai status perusahaan di industri, reputasi dewan direksi, produk dan layanan perusahaan, sehingga investor yang memiliki pengetahuan keuangan yang baik akan cenderung tidak mempertimbangkan citra diri perusahaan dalam keputusan investasi saham.

$$
\text { Al-Tamimi dan Kalli }
$$
menyatakan bahwa seorang Investor yang memiliki pengetahuan keuangan yang tinggi akan lebih cenderung menempatkan dananya pada investasi yang memiliki resiko yang tinggi, sehingga seorang investor yang memiliki pengetahuan yang tinggi akan lebih mentoleransi resiko yang ada salah satunya dengan cara tidak terlalu mempertimbangkan hal yang kurang penting contohnya yaitu dimensi Citra Diri Perusahaan.

Hasil penelitian ini sama dengan hasil penelitian sebelumnya yang dilakukan oleh Al-Tamimi dan Kalli (2009), bahwa terdapat pengaruh negatif antara pengetahuan keuangan terhadap Citra Diri Perusahaan 
dalam Keputusan Investasi saham. Hasil penelitian Khasif Arif (2015), bahwa literasi keuangan berpengaruh negatif terhadap keputusan investasi.

\section{Pengetahuan Keuangan Terhadap Informasi Rujukan (Y2)}

Pengujian hipotesis diperoleh hasil yang menyatakan bahwa terdapat pengaruh negative signifikan.Hal ini dapat dilihat pada tabel 6 nilai $\mathrm{B}$ (beta) sebesar -0.80 dan memiliki Pvalue $\mathrm{P}<0.01$ artinya lebih kecil dari (<) 0.05, sehingga dapat dikatakan bahwa Pengetahuan Keuangan memiliki pengaruh negative signifikan terhadap Informasi Rujukan dalam Keputusan Investasi Saham. Artinya semakin baik pengetahuan keuangan yang dimiliki oleh seorang investor maka cenderung tidak mempertimbangkan Informasi Rujukan dalam mengambil sebuah keputusan investasi saham.

Seorang investor yang memiliki pengetahuan keuangan yang tinggi atau baik akan lebih menunjukan sikap yang lebih baik dalam mengambil sebuah keputusan investasi. Sebuah pengetahuan keuangan yang baik akan memberikan dampak yang baik terhadap seorang investor yaitu salah satunya jika seorang investor memiliki pengetahuan yang baik maka akan cenderung lebih percaya diri dalam mengambil sebuah keputusan dibandingkan dengan investor yang kurang akan sebuah pengetahuan, sehingga seorang investor yang memiliki pengetahuan yang baik atau tinggi cenderung tidak mempertimbangkan Informasi Rujukan dalam keputusan investasinya, sehingga tidak membutuhkan informasi dari teman, keluarga, broker atau koran.

Hasil penelitian ini sama dengan penelitian yang dilakukan oleh Khasif Arif (2015), bahwa literasi keuangan berpengaruh negatif terhadap keputusan investasi.

\section{Pengetahuan Keuangan Terhadap Informasi Keuangan (Y3)}

Pengujian hipotesis diperoleh hasil yang menyatakan bahwa terdapat pengaruh positif signifikan. Hal ini dapat dilihat pada tabel 6 nilai B (beta) sebesar 0.28 dan memiliki Pvalue $\mathrm{P}<0.01$ artinya lebih kecil dari $(<) \quad 0.05$, sehingga dapat dikatakan bahwa Pengetahuan Keuangan memiliki pengaruh positif signifikan terhadap Informasi Keuangan dalam Keputusan Investasi Saham. Artinya semakin baik pengetahuan keuangan yang dimiliki oleh seorang investor maka cenderung mempertimbangkan Informasi Keuangan dalam mengambil sebuah keputusan investasi saham.

Seorang investor yang mempunyai pengetahuan yang tinggi akan cenderung mempertimbangkan informasi saham sebuah perusahaan dalam mengambil sebuah keputusan investasi karena investor yang mempunyai pengetahuan yang tinggi merasa memiliki kemampuan dalam bidang keuangan misalnya menganalisis kinerja saham dimasa lalu. Seorang investor yang memiliki pengetahuan yang baik akan lebih mengerti tentang kinerja saham di perusahaan, harga saham di pasar, dan pertumbuhan perusahaan dari sisi laporan keuangannya, sehingga seorang investor yang memiliki pengetahuan yang baik akan cenderung mempertimbangkan Informasi Keuangan terhadap keputusan investasi sahamnya.

Hasil penelitian ini sama dengan hasil penelitian yang dilakukan oleh Al-Tamimi dan Kalli (2009) bahwa pengetahuan keuangan berpengaruh positif signifikan terhadap informasi keuangan. Howlett et al (2008), bahwa pengetahuan keuangan berpengaruh positif terhadap keputusan keuangan jangka panjang baik terhadap keputusan dana pensiun maupun keputusan investasi.

Pengaruh Risk Tolerance Terhadap Keputusan Investasi Saham 
Hipotesis kedua dalam penelitian ini digunakan untuk membuktikan apakah risk tolerance mempengaruhi keputusan investasi saham. Berikut hasil pengujian hipotesis tersebut :

\section{Risk Tolerance Terhadap Citra Diri Perusahaan (Y1)}

Pengujian hipotesis diperoleh hasil yang menyatakan bahwa terdapat pengaruh negative tidak signifikan. Hal ini dapat dilihat pada tabel 6 nilai B (beta) sebesar -0.12 dan memiliki Pvalue $\mathrm{P}=0.10$ artinya lebih besar dari (>) 0.05, sehingga dapat dikatakan bahwa Risk Tolerance memiliki pengaruh negatif tidak signifikan terhadap Citra Diri Perusahaan dalam Keputusan Investasi Saham. Dilihat dari Tabel 6 nilai B (beta) yang dihasilkan sebesar -0.12, artinya semakin tinggi risk tolerance yang dimiliki oleh seorang investor maka cenderung tidak mempertimbangkan Citra Diri Perusahaan dalam mengambil sebuah keputusan investasi saham, tetapi hal ini tidak signifikan karena memiliki Pvalue $>0.05$.

Dalam penelitian ini variabel risk tolerance tidak berpengaruh terhadap Citra Diri Perusahaan, artinya seorang investor yang memiliki risk tolerance yang tinggi cenderung tidak mempertimbangkan Citra Diri Perusahaan dalam mengambil sebuah keputsan investasi, hal ini disebabkan bawah seoarang investor yang memiliki risk tolerance tinggi akan lebih cenderung lebih berani bertindak maupun mengambil sebuah keputusan (berani mengambil risiko), sehingga Citra Diri Perusahaan merupakan hal yang dapat ditoleransi dalam mengambil sebuah keputusan investasi saham.

Kavita dan Prasaranna menyatakan bahwa hanya para investor yang memiliki toleran resiko tinggi yang akan bersedia berinvestasi di saham, dengan harapan mendapatkan return yang tinggi pula, tinggi rendahnya toleransi resiko seorang investor didukung oleh tingkat pengetahuan yang mereka miliki, mayoritas seorang investor yang memiliki pengetahuan banyak akan memiliki toleransi resiko yang tinggi. Hal ini di dukung pada Tabel 4 pada skoring pengetahuan responden dalam penelitian ini memiliki pengetahuan yang cukup, sehingga responden cenderung memiliki sikap toleransi terhadap resiko yang tinggi. Investor yang memiliki sifat risk tolerance tinggi cenderung tidak mempertimbangkan citra diri perusahaan dalam pengambilan keputusan investasi meskipun perusahaan tersebut kurang terkenal karena investor tersebut cenderung memilih investasi dengan resiko yang tinggi dengan harapan mendapatkan keuntungan yang tinggi pula.

\section{Risk Tolerance Terhadap Informasi Rujukan (Y2)}

Pengujian hipotesis diperoleh hasil yang menyatakan bahwa terdapat pengaruh positif tidak signifikan. Hal ini dapat dilihat pada tabel 4.6 nilai B (beta) sebesar 0.08 dan memiliki Pvalue $\mathrm{P}=0.21$ artinya lebih besar dari (>) 0.05, sehingga dapat dikatakan bahwa Risk Tolerance memiliki pengaruh positif tidak signifikan terhadap Informasi Rujukan dalam Keputusan Investasi Saham.

Dalam penelitian ini variabel risk tolerance tidak berpengaruh terhadap Informasi Rujukan, artinya seorang investor yang memiliki risk tolerance yang tinggi cenderung tidak mempertimbangkan Informasi Rujukan dalam mengambil sebuah keputsan investasi, hal ini disebabkan bawah seoarang investor yang memiliki risk tolerance tinggi akan lebih cenderung lebih berani bertindak maupun mengambil sebuah keputusan (berani mengambil risiko), sehingga Informasi Rujukan merupakan hal yang dapat ditoleransi dalam mengambil sebuah keputusan investasi saham.

Kavita dan Prasaranna menyatakan bahwa tinggi rendahnya toleransi resiko seorang investor didukung oleh tingkat pengetahuan yang mereka miliki, mayoritas seorang investor yang memiliki pengetahuan banyak akan memiliki toleransi resiko yang 


\section{Balance: Economic, Business, Management, and Accounting Journal \\ Vol. XVII No. 1 | Bulan Januari Tahun 2020}

tinggi. Pada Tabel 4 dapat diketahui bahwa responden dalam penelitian ini memiliki pengetahuan yang cukup baik dan Tabel 5 menunjukan bahwa responden memiliki tingkat toleransi resiko (risk tolerance), sehingga memungkinkan bahwa responden dalam penelitian ini tidak mempertimbangkan Informasi Rujukan, sehingga cenderung mengabaikan informasi dari teman, keluarga broker maupun koran.

\section{Risk Tolerance Terhadap Informasi} Keuangan (Y3)

Pengujian hipotesis diperoleh hasil yang menyatakan bahwa terdapat pengaruh positif signifikan. Hal ini dapat dilihat pada tabel 4.6 nilai $\mathrm{B}$ (beta) sebesar 0.18 dan memiliki Pvalue $\mathrm{P}=0.03$ artinya lebih besarkecil $(<) 0.05$, sehingga dapat dikatakan bahwa Risk Tolerance memiliki pengaruh positif signifikan terhadap Informasi Keuangan dalam Keputusan Investasi Saham.

Dalam penelitian ini variabel risk tolerance berpengaruh positif signifikan terhadap Informasi Keuangan, artinya seorang investor yang memiliki risk tolerance yang tinggi cenderung mempertimbangkan Informasi Keuangan dalam mengambil sebuah keputsan investasi, hal ini disebabkan bawah menurut Kavita dan Prasaranna (2016) menyatakan bahwa tinggi rendahnya toleransi resiko seorang investor didukung oleh tingkat pengetahuan yang mereka miliki, mayoritas seorang investor yang memiliki pengetahuan banyak akan memiliki toleransi resiko yang tinggi, sehingga seorang investor yang memiliki risk tolerance yang tinggi cenderung memiliki pegetahuan yang baik.

Hal ini didukung pada Tabel 4 dapat diketahui bahwa responden dalam penelitian ini memiliki pengetahuan yang cukup baik, sehingga responden dalam penelitian ini akan cenderung mempertimbangkan informasi saham sebuah perusahaan dalam mengambil sebuah keputusan investasi karena investor yang mempunyai pengetahuan yang tinggi merasa memiliki kemampuan dalam bidang keuangan misalnya menganalisis kinerja saham dimasa lalu, sehingga seorang investor yang memiliki risk tolerance yang tinggi akan cenderung mempertimbangkan Informasi Keuangan terhadap keputusan investasi sahamnya.

\section{Pengaruh Risk Tolerance Terhadap Keputusan Investasi Saham dengan Gender sebagai Variabel Moderasi}

Hipotesis ketiga dalam penelitian ini digunakan untuk membuktikan apakah gender dapat memoderasi pengaruh risk toleranceterhadap keputusan investasi saham. Pada Tabel 6 menunjukan bahwa pengujian hipotesis diperoleh hasil yang menyatakan bahwa tidak ada pengarauh variabel gender dalam memoderasi pengaruh risk tolerance terhadap Citra Diri Perusahaan (Y1), Informasi Rujukan (Y2) dan Informasi Keuangan (Y3) dalam keputusan investasi saham, hal ini dapat Pvalue yang dihasilkan $>0.05$.

Artinya dalam peneltian ini gender tidak memperkuat pengaruh risk tolerance terhadap keputusan investasi saham, sehingga investor laki-laki tidak selalu cenderung memiliki sikap risk tolerance yang tinggi dibandingkan investor wanita. Menurut Syed dan Khaliquzzaman (2016) menyatakan bahwadi dunia modern saat ini di mana perempuan lebih berpendidikan, lebih banyak bekerja dan berpengetahuan luas, mereka sudah mulai mengambil keputusan investasi mereka sendiri, sehingga perempuan juga berani dalam mengambil sebuah risiko (risk tolerance tinggi). Hal ini memungkinkan bahwa responden wanita dalam penelitian ini memiliki pendidikan maupun pengetahuan yang sama dengan laki-laki, sehingga tingkat risk tolerance yang dimiliki sama.

Hasil penelitian ini sama dengan hasil penelitian yang dilakukan oleh Wiwik Lestari \& Siti (2011), bahwa variabel gender tidak memoderasi pengaruh religiusitas dan persepsi resiko dalam pengambilan keputusan 
investasi. Hasil penilitian Ikeobi et al (2016), bahwa faktor demografi seperti gender tidak berpengaruh signifikan tehadap keputusan investasi. Hasil penelitian Mathanika et al (2017), bahwa sedangkan gender tidak memiliki pengaruh signifikan terhadap pengambilan keputusan investasi.

\section{KESIMPULAN}

hasil analisa yang telah dilakukan baik secara deskriptif maupun statistik menggunakan SEM pada WarpPLS maka berdasarkan hasil uji hipotesis yang telah dilakukan dalam penelitian ini dapat diambil disimpulkan bahwa (1) Pengetahuan keuangan berpengaruh negatif signifikan terhadap citra diri perusahaan dan informasi rujukan, namun berpengaruh positif signifikan terhadap informasi keuangan dalam keputusan investasi saham (2) Risk tolerance tidak berpengaruh terhadap citra diri perusahaan dan informasi rujukan, namun berpengaruh positif signifikan terhadap informasi keuangan dalam keputusan investasi saham (3) Gender tidak dapat memoderasi pengaruh antara risk tolerance terhadap keputusan investasi saham (citra diri perusahaan, informasu rujukan dan informasi keuangan.

Berdasarkan hasil analisis penelitian yang telah disimpulkan, maka peneliti dapat memberikan saran-saran yang dapat bermanfaat bagi pihak-pihak yang terkait dalam penelitian ini yaitu bagi investor yaitu diharapkan pengambil keputusan investasi saham lebih memahami dan mempelajari mengenai dimensi-dimensi (citra diri perusahaan, informasi rujukan dan informasi keuangan) yang harus dipertimbangkan dalam menentukan keputusan investasinya; bagi peneliti selanjutnya (1) Diharapkan dalam memperluas penyebaran kuesioner maupun google form (2) Diharapkan menggunakan variabel bebas yang tidak terdapat dalam model penelitian ini, misalkan variabel Over Convidence atau Pengalaman, agar model yang diperoleh dapat memberikan hasil yang lebih baik; bagi broker yaitu diharapkan untuk menyampaikan informasi yang lebih akurat dan mengedukasi investor untuk lebih meyakinkan investor.

\section{DAFTAR PUSTAKA}

Abdul Halim, 2005, AnalisisInvestasi, Edisipertama, Jakarta :SalembaEmpat.

Al-Tamimi, HAH danKalli, A, 2009."Financial Literacy and Investment Decisions of UAE Investors". The Journal of Risk Finance.Vol.10, No. 5. Pp 500-516.

Angga Budiarto dan Susanti. 2017. Pengaruh Financial Literacy, Overconfidence,Regret Aversion Bias, dan Risk Tolerance terhadap Keputusan Investasi.Jurnal Ilmu Manajemen. Vol.5, no.2, hal.1-9

Ansari, sarfaraz \& Uprety, minal. (2017 ). Investors Perception Towards Determinant Of Investment Decision: A Gender Based Study. International Education \& Research Journal, Vol.3, No.6.

Arif, Kashif. (2015). Financial Literacy And Other Factors Influencing Individuals' Investment Decision: Evidence From A Developing Economy (Pakistan). Journal Of Poverty, Investment And Development, Vol. 12

Bodie, Z., Kane, A., dan Marcus, AJ. (2011) Investments and Portofolio Management. Global Edition. New York : The McGraw-Hill Companies, Inc.

Campbell NA,Reece JB, Urry LA, Cain ML, Wasserman SA, Minorsky PV,et. al. Biologi.5thed .Jakarta.PenerbitErlangga ; 2006.

Chavali, Kavita \& Mohanraj, M. Prasanna. (2016). Impact of Demographic Variables and Risk Tolerance on Investment Decisions: An Empirical Analysis. International Journal of Economics and Financial, Vol. 6 issue 1, 169. 175

Duda, H.F., Bruhin, A., Epper, T., Sehubert, R. (2010), Rationality on the rise: Why relative risk aversion increases with stake size. Journal of Risk and Uncertainty, 40(2), 147-180.

Eduardus Tandelilin. 2010. Portofolio dan Investasi Teori dan Aplikasi. Edisi Pertama. Yogyakarta: Penerbit Kanisius.

Hilgert, Marianne, Hogart J, and Beverly SG, 2003. "Household Financial Management: The Connection between Knowledge and Behavior". Federal Reserve Bulletin. Vol. 89 (July). Pp 310322 


\section{Balance: Economic, Business, Management, and Accounting Journal Vol. XVII No. 1 | Bulan Januari Tahun 2020}

Howlett, Elizabet.,Kees, Jeremy., and Kemp, Elyria. (2008). "The Role of Self-Regulation, Future Orientation, and Financial Knowledge in LongTerm Financial Decisions". The Journal of Consumer Affairs.Vol 42 No. 2, Summer : 223 -242 .

Huston, SJ 2010, 'Measuring financial literacy', Journal of Consumer Affairs, Vol. 44, No. 2, 296-316.

Ikeobi \& Arinze. (2016). The Influence Of Demographic Factors On The Investment Objectives Of Retail Investors In The Nigerian Capital Market. European Journal Of Business And Management, Vol. 8, No.11

Jamil, Syed Ahsan \& Khan, Khaliquzzaman. (2016). Does Gender Difference Impact Investment Decisions? Evidence From Oman. International. Journal Of Economics And Financial, Issues $6(2), 456-460$

Jianakoplos, A, Nancy., and Alexandra Bernasek.,(1998), " Are Women More Risk Averse?" Economic Inquiry, XXXVI, October, $620-630$

Lusardi, A, 2008. "Financial Literacy: An Essential Tool for Informed Consumer Choice?".NBERWorking Paper Series. Pp 1-29.

Maditinos, D., Sevic, Z danTheriou, N, 2007."Investors' behavior in the Athens Stock Exchange (ASE)".Studies in Economics and Finance.Vol.24, No. 1. Pp 32-50.
Mathanika.T, Tharshiga.P \& Dr.R.Yogendrarajah (2017). Demographic Factor And Individual Investment Decision Making. European Journal Of Business And Management, Vol. 9, No. 15

Mittal, Manish and RK Vyas, 2011, A'Study of Psychological Reasons forGender Differences in Preferences forRisk and Investment DecisionMaking', The IUP. Journal of Behavioral Finance, Vol. VIII, No. 3, hal. 45-60.

Moreschi, Robert W. (2005). An Analysis of the Ability of Individuals to Predict Their Own Risk Tolerance. Volume 3.Halaman 39-48

Mudrajad Kuncoro. 2013. "Metode Riset untuk Bisnis dan Ekonomi”. Edisi 14 Jakarta :Salemba Empat..

Nofsinger, Jhon R. 2015. Psychology of Investing. Second Edition. New Jersey Prentice Hall Inc.

Pompian, Michael, M. 2006.Behavioral Finance and Wealth Management.NewYork : John Wiley \&amp; Sons, Inc

Roszkowski, M. J., \& Snelbecker, G. E. (1990). Effects of "framing" on measures of risk tolerance: Financial planners are not immune. Journal of Behavioral Economics, 19(3), 237-246

Seligman, E. P. M., \& Peterson, C. (2004). Character Strengths and Virtues, A Handbook and Classification. American Psychological Association. New York : Oxford University Press 